\title{
Czas usiłowania i dokonania kradzieży w sklepie samoobsługowym
}

\author{
TOMASZ TYBURCY \\ ORCID: 0000-0001-8549-6460 \\ Katedra Prawa Karnego \\ Wydział Prawa i Administracji Uniwersytetu Warszawskiego
}

Zgodnie z art. 278 § 1 k.k. kto zabiera w celu przywłaszczenia cudzą rzecz ruchomą, podlega karze pozbawienia wolności od 3 miesięcy do 5 lat. W ciągu wieków występowały różne teorie dotyczące czasu dokonania kradzieży. Obecnie powszechnie przyjmuje się teorię zawładnięcia.

W literaturze podnosi się, że cel przywłaszczenia teoretycznie można ujmować w dwóch odmiennych wersjach ${ }^{1}$. Pierwsza z nich akcentuje aspekt pozytywny, to jest zamiar postąpienia z rzeczą jak właściciel i korzystanie z niej w sposób wskazujący na wykonywanie praw właścicielskich. W ten sposób odróżnia się kradzież od zaboru w celu krótkotrwałego użycia. Natomiast drugie ujęcie wskazuje na aspekt negatywny, czyli trwałe pozbawienie pokrzywdzonego możliwości korzystania z rzeczy. Może ono pomagać w odróżnieniu kradzieży od zniszczenia rzeczy czy też jej ukrycia w celu wyrządzenia krzywdy właścicielowi. W praktyce aspekt negatywny bardzo rzadko jest objęty celem. Właściwe rozumienie celu przywłaszczenia powinno opierać się na obydwu tych koncepcjach i być niejako ich wypadkową.

1 T. Oczkowski, A. Marek, [w:] System prawa karnego, t. 9, Przestępstwa przeciwko mieniu i gospodarcze, red. R. Zawłocki, Warszawa 2011, s. 80. 
Kradzież jest przestępstwem (wykroczeniem) materialnym. Dokonuje się w momencie realizacji znamienia skutku, czyli zaboru cudzej rzeczy ruchomej w celu przywłaszczenia. E. Krzymuski pisał, że

ponieważ kradzież jest zaborem cudzej rzeczy, przeto jasną jest rzeczą, że może ona uchodzić za przestępstwo dokonane dopiero z chwilą, gdy winowajca już zabrał odnośną rzecz z posiadania drugiego. Kiedy jednak trzeba będzie uważać zabór rzeczy za fakt już spełniony? Cztery różne teorye przyjąć można za podstawę dla rozstrzygnięcia tej kwestyi. Są niemi: a) teorya pochwycenia (Kontrektationstheorie) ${ }^{2}$, według której rzecz ma uchodzić za zabraną już w chwili, gdy winowajca wziął ją w swoje ręce; b) teorya owładnięcia (Aprehensionstheorie), z punktu widzenia której o zaborze rzeczy, jako fakcie spełnionym, może być mowa dopiero z chwilą, gdy winowajca wziął rzecz w swoje dzierżenie; c) teorya wyniesienia (Ablationstheorie), która uważa rzecz za zabraną wtedy, gdy winowajca usunął ją z miejsca, gdzie znajdowała się w dzierżeniu drugiego; i wreszcie d) teorya przechowania (Illationstheorie), która dla zaboru rzeczy żąda, aby winowajca już zdołał ją ukryć przed dotychczasowym jej dzierżycielem. Z czterech powyższych teoryj, pierwsza chce zbyt wcześnie uważać zabór rzeczy za spełniony, podczas znów, gdy trzecia i czwarta czynią zabór rzeczy zależnym od działań, które właściwie są tylko następstwem już dokonanego zaboru. Słuszność ma za sobą tylko teorya owładnięcia, gdyż kładzie ona nacisk na to, co ma znaczenie istotne dla pojęcia zaboru, a mianowicie na przejście rzeczy z dzierżenia dotychczasowego posiadacza w dzierżenie zaborcy. Do tej teoryi przychyla się takie z pewnemi zastrzeżeniami najwyższa judykatura austryacka ${ }^{3}$.

Cytowany autor podaje przykład orzeczenia austriackiego Najwyższego Trybunału, który uznał, że zwierzyna zabita w cudzym lesie jest „zabrana” nie z chwila jej ukrycia, lecz wyniesienia z lasu.

W. Makowski wskazywał, że zawładnięcie rzeczą, czyli objęcie w posiadanie całkowite, może nastąpić nawet na czas krótki, a kradzież będzie dokonana ${ }^{4}$. Jego zdaniem kradzież jest dokonana bez względu na to, czy złodziejowi udało się zamiar rozporządzania rzeczą jak swoją własnością urzeczywistnić, czy też przeszkodzono mu w tym, ją odbierając. Trafnie zauważał, że nie „przywłaszczenie”, lecz „zabór w celu przywłaszczenia" jest znamieniem czasownikowym kradzieży5. Teorię

2 Przyjmowano ją w prawie rzymskim.

3 E. Krzymuski, Wykład prawa karnego ze stanowiska nauki i prawa austryackiego, t. 2, Kraków 1902, s. 236. Tak też S. Budziński, O przestępstwach w szczególności. Wykład porównawczy z uwzględnieniem praw obowiąujących na Królestwie Polskiem i Galicyi Austryackiej, Warszawa 1883, s. 160.

${ }^{4}$ W. Makowski, Kodeks karny. Komentarz, Warszawa 1932, s. 765.

5 Ibidem, s. 768.

Nowa Kodyfikacja Prawa Karnego 51, 2019

(C) for this edition by CNS 
uniesienia, którą można uznać za archaiczną, przyjmowało prawo angielskie w XVIII wieku' .

Przyjęcie teorii zawładnięcia rozstrzyga, kiedy kradzież jest dokonana. Nie determinuje ona jednak odpowiedzi na pytanie, kiedy sprawca realizuje swój cel działania, czyli gdy przywłaszcza rzecz. W piśmiennictwie zarysowały się więc dwie koncepcje. Zwolennicy pierwszej z nich ${ }^{7}$ uważają ,zabór w celu przywłaszczenia” za działanie dwuaktowe. Kradzież jest dokonana w momencie zaboru, a nie w czasie przywłaszczenia, które następuje potem. Przywłaszczenie jest celem zaboru, którego realizacja nie jest konieczna do dokonania przestępstwa. Natomiast przedstawiciele drugiej koncepcji ${ }^{8}$ stoją na stanowisku, że „zabór w celu przywłaszczenia" to działania jednoaktowe, ponieważ akt zaboru oznacza również przywłaszczenie rzeczy. Mamy wtedy do czynienia $\mathrm{z}$,zaborem przywłaszczeniowym”. Zdaniem R. Honiga pod względem faktycznym można oddzielić „zabór” od „przywłaszczenia”. Autor wskazuje, że znamieniem kradzieży jest „,zabór w celu przywłaszczenia", a więc zabór musi być realizacją celu przywłaszczenia, czyli przywłaszczeniem. W. Wolter podkreśla, że ten pogląd lepiej oddaje rzeczywistość niż wymagający urzeczywistnienia przywłaszczenia oddzielnym aktem. Takie ujęcie pozwala też odróżnić kradzież od tych przestępstw celowościowych, których czas dokonania leży przed realizacją celu, na przykład art. 270 k.k., kiedy sprawca podrabia lub przerabia dokument „w celu użycia za autentyczny”. Powołany autor podkreśla, że zwolen-

${ }^{6}$ W. Blackstone, Prawo Kryminalne Angielskie, Warszawa 1786, s. 309. Za kradzież nie uznawano samego przeniesienia rzeczy z miejsca jednako w drugie. Natomiast, gdy sprawca „chcąc unieść sztukę srebrną z zamknięcia, upuszcza ją, łoskot czyni i przytrzymany zostaje; takie i tym podobne przykłady właściwey dowodzą kradzieży".

7 S. Frankowski, Przestępstwa kierunkowe w teorii i praktyce, Warszawa 1970, s. 83; S. Śliwiński, Prawo karne, Warszawa 1946, s. 413-416.

8 W. Wolter, Reguly wylaczania wielości ocen w prawie karym, Warszawa 1961, s. 115-116; O. Górniok, Zagarnięcie mienia społecznego, Warszawa 1976, s. 166-167; R. Honig, Straflose Vor-und Nachtat, Leipzig 1927, s. 96; A. Marek, [w:] A. Marek, E. Pływaczewski, A. Peczeniuk, Kradzież i paserstwo mienia prywatnego, Warszawa 1985, s. 56. Tak też J. Makarewicz (Kodeks karny z komentarzem, Lwów 1932, s. 446), który pisał, że złodziej trzymający w ręce przed chwilą skradziony portfel jest w bezpośrednim jego władaniu.

9 R. Honig, op. cit., s. 95 n. 
nicy uznawania zaboru w celu przywłaszczenia za czynność dwuaktową muszą sam akt przywłaszczenia traktować z punktu widzenia zasady konsumpcji ${ }^{10}$.

Inni autorzy wskazują, że do stwierdzenia „zaboru” bez znaczenia jest realizacja przywłaszczenia. Fakt przywłaszczenia jest jedynie celem działania sprawcy. Może on być zrealizowany dopiero po dokonaniu zaboru. Nieistotne jest w kwestii dokonania zaboru, czy sprawca zrealizuje zamiar przywłaszczenia. Zabór jest zakończony z chwilą kompletnego zawładnięcia mieniem, a nie $\mathrm{z}$ chwilą jego przywłaszczenia. Moment przywłaszczenia może wcale nie zaistnieć mimo dokonania zaboru ${ }^{11}$.

Trafnie podkreśla SN, że zabór cudzego mienia w rozumieniu art. $278 \S 1 \mathrm{k} . \mathrm{k}$.

polega na pozbawieniu władztwa określonej osoby nad danym przedmiotem i na przeniesieniu tego władztwa na osobę sprawcy kradzieży. Jeżeli nawet przyjąć, że oskarżona nie wyjęła pieniędzy i dokumentów z torebki pokrzywdzonej, lecz że pieniądze te wraz $\mathrm{z}$ dokumentami wypadły $\mathrm{z}$ torebki pokrzywdzonej i dopiero $\mathrm{w}$ tym momencie oskarżona przystąpiła do ich zaboru, to i w takim wypadku dopuściła się ona kradzieży, a nie przywłaszczenia mienia znalezionego, gdyż przez wypadnięcie pieniędzy z torebki w sklepie, tuż obok stóp pokrzywdzonej w momencie, gdy w sklepie jeszcze ona pozostawała, nie utraciła ona jeszcze władztwa nad tymi pieniędzmi i nie mogą być one uważane za zgubione, a nadto oskarżona nie mogła nie wiedzieć, stojąc obok pokrzywdzonej, że pieniądze stanowiły własność tej ostatniej ${ }^{12}$.

W. Gutekunst wskazuje, że zabór jako element przedmiotowy przestępstwa kradzieży polega na zawładnięciu (pochwyceniu) rzeczy w momencie kradzieży oraz przejęciu go w swoje władztwo. Zabór w rozumieniu art. $278 \S 1$ k.k. zachodzi, gdy sprawca faktycznie w jakikolwiek sposób zabrał rzecz i nią zawładnął. Zabór to czynność składająca się z ruchów fizycznych, które urzeczywistniają wyjęcie mienia spod władztwa pokrzywdzonego i przeniesienia we władanie sprawcy. Zespół ruchów składających się na zabór może cechować różne natężenie siły fizycznej. Różnorakie mogą być też formy zaboru. Zabór oznacza użycie siły fizycznej w celu przełamania oporu stawianego przez daną przeszkodę. Mogą być nią rzeczy lub zjawiska stojące miedzy sprawcą a przed-

${ }^{10}$ W. Wolter, op. cit., s. 115-116.

11 W. Gutekunst, Zabór jako sposób zagarnięcia mienia spolecznego, NP 1955, s. 61.

12 Wyrok SN z dnia 14 grudnia 1945 r., K 289/45, OSN(K) 1945, nr 1-2, poz. 23.

Nowa Kodyfikacja Prawa Karnego 51, 2019

(C) for this edition by CNS 
miotem wykonawczym. Natura tych przeszkód wyznacza stopień siły fizycznej koniecznej do zaboru. Zabór przełamuje władztwo rozumiane jako stan faktyczny, a nie prawny. Zdaniem wskazanego autora władztwo jest faktyczną mocą nad mieniem i nie można jej utożsamiać z posiadaniem w rozumieniu prawa cywilnego. Zabór w rozumieniu art. 278 $\S 1$ k.k. ma miejsce tylko wtedy, gdy sprawca wyłącza mienie bezprawnie poza granice władztwa pokrzywdzonego. Są one określone danymi układami faktycznymi ${ }^{13}$.

Ustalenie momentu, w którym nastąpiło zawładnięcie rzeczą, od dawna budziło kontrowersje. Nawet zwolennicy teorii zawładnięcia, na przykład W. Makowski, wymagali wyniesienia rzeczy, poza dom pokrzywdzonego. Wydaje się, że nie jest to kwestia przyjęcia teorii zawładnięcia lub wyniesienia. Sprawca może zawładnąć rzeczą, dopiero gdy wyniesie ją poza nieruchomość pokrzywdzonego. W mojej opinii teorie zawładnięcia i wyniesienia w tym wypadku nie wykluczają się, lecz raczej uzupełniają. Jeżeli przyjąć, że zawładnięcie następuje po opuszczeniu przez sprawcę nieruchomości pokrzywdzonego, to teoria wyniesienia traci rację bytu, gdyż zostaje pochłonięta przez szersze rozumienie pojęcia zawładnięcia. Wyodrębnianie teorii wyniesienia ma według mnie sens jedynie w odniesieniu do przypadków kradzieży poza nieruchomością pokrzywdzonego. W tym wypadku jednak także należy przyjmować teorię zawładnięcia. Jeżeli więc sprawca kradnie portfel w tramwaju, do stwierdzenia dokonania nie jest konieczne opuszczenie przez niego wagonu.

Sporną kwestią jest czas usiłowania i dokonania kradzieży, gdy miejscem czynu jest sklep samoobsługowy. W szczególności istotne jest prawidłowe ustalenie czasu usiłowania i oddzielenie niekaralnych czynności przygotowawczych od karalnego usiłowania kradzieży. Analiza wszystkich dogmatycznych teorii usiłowania wykracza poza ramy tej pracy. Krytycznie należy odnieść się do teorii subiektywnych ${ }^{14}$. Dlatego

13 W. Gutekunst, op. cit., s. 51-56.

14 W szczególności do tej niewprowadzającej żadnych elementów wskazujących na charakter woli przestępnej. Zgodnie z nią zamiar może być wyprowadzony z dowolnego zachowania sprawcy. W momencie przystąpienia do realizacji zamiaru następuje jego obiektywizacja. Zob. E. Krzymuski, System prawa karnego ze stanowiska nauki $i$ trzech kodeksów obowiązujących w Polsce, Kraków 1921, s. 136. Inna z teorii podmiotowych

Nowa Kodyfikacja Prawa Karnego 51, 2019

(C) for this edition by CNS 
też moje rozważania będę prowadził wyłącznie na gruncie teorii formalnoobiektywnej i materialnoobiektywnej.

Można wyróżnić pięć punktów czasowych relewantnych dla określenia czasu usiłowania oraz dokonania kradzieży:

1. zabranie rzeczy z półki,

2. schowanie towaru do torby lub kieszeni,

3. ustawienie się w kolejce do kasy,

4. przekroczenie bramki kasowej bez płacenia za daną rzecz,

5. opuszczenie sklepu.

Według pierwszej wersji teorii formalnoobiektywnej usiłowanie następuje, gdy sprawca już rozpoczął wypełnianie znamienia czasownikowego $^{15}$. Moim zdaniem w świetle tej teorii czynność zaboru następuje w momencie przechodzenia przez bramkę kasową. Jeżeli sprawca zostanie zatrzymany po jej przekroczeniu, to kradzież została dokonana.

operuje pojęciem ,zbliżenia się sprawcy do miejsca czynu przestępnego”, które potwierdza „,bezpośredniość”. Wprowadza więc ona kryterium przedmiotowe w celu rozpoznania woli sprawcy. Trafnie wskazuje G. Rejman (Usiłowanie przestęstwa w prawie polskim, Warszawa 1965, s. 31-32), że obserwowanie sklepu w celu dokonania kradzieży nie powinno być kwalifikowane jako usiłowanie tylko z tego powodu, że sprawca zbliżył się znacznie do przedmiotu wykonawczego. Jednocześnie podkreśla ona, że „obserwacja może stanowić działanie »bezpośrednio« poprzedzające dokonanie kradzieży, ale dopiero wówczas, jeżeli sprawca uzbrojony w narzędzie przestępstwa przybył już na miejsce przestępstwa z myślą jego dokonania. Obserwowanie przedmiotu wykonawczego było już w tych warunkach jedną z końcowych czynności poprzedzających wtargnięcie do sklepu i kradzież mienia. Natomiast jeżeli obserwacja nie była poprzedzona jeszcze takimi czynnościami, to nie wykracza ona poza działanie przygotowawcze”. Teorie upatrujące istotę „bezpośredniości” zarówno w bliskości miejsca, jak i w czasowym zbieganiu się z czynnościami dokonania nie są zadowalające. Istnieją także teorie podmiotowe, które opierają się na czynniku psychologicznym. W doktrynie wskazuje się (G. Rejman, op. cit., s. 35-36), że usiłowanie zaczyna się w momencie ukierunkowania woli na realizację pierwszej czynności, która „według mniemania sprawcy jest związana z dokonaniem przestępstwa nieprzerwanego łańcuchem pośrednich aktów". Wydaje się, że teoria ta znacznie rozszerza zakres karalnego usiłowania. Zachowanie sprawcy powinno potwierdzić jego zamiar poprzez czynniki psychologiczne, na przykład stanowczość zamiaru lub emocjonalne zaangażowanie w działanie przestępne. Jej zwolennikiem był J. Śliwowski. Zob. Glosa do postanowienia SN z dnia 16 grudnia 1957 r., KO 139/51, OSP, poz. 79.

15 Zob. E. Kunze, Przygotowanie przestępstwa w ujęciu polskiego prawa karnego, Poznań 1991, s. 71. 
Usiłowanie trwa więc bardzo krótko i w zasadzie niemożliwe jest uchwycenie czasu, w którym następuje.

Druga wersja teorii formalnoobiektywnej przyjmuje, że czas usiłowania jest wyznaczony przez podjęcie ostatniej czynności, która przy uwzględnieniu zamiaru sprawcy i planu jego działania ma prowadzić do dokonania. Nazywana jest ona teorią planu działania sprawcy.

Bezpośredniość rozstrzygająca o usiłowaniu, zachodzi wtedy, gdy biorąc za podstawę plan działania sprawcy i przedmiotowo rzecz oceniając dochodzimy do wniosku, że dany wycinek przestępnego zachowania sprawcy jest już ostatnią fazą tej działalności, którą według nowego planu ma wykonać ${ }^{16}$.

Tą ostatnią fazą jest nie tylko urzeczywistnienie samej czynności czasownikowej, lecz także to, co bezpośrednio wyprzedza czynność czasownikową ${ }^{17}$. Wydaje się, że zgodnie z tą koncepcją usiłowanie kradzieży zachodzi w momencie ustawienia się w kolejce do kasy.

Według teorii materialnoobiektywnych o bezpośredniości rozstrzyga stopień zagrożenia dobra prawnego. Usiłowanie następuje, jeżeli stan zagrożenia dobra prawnego nie jest już abstrakcyjny (przygotowanie), lecz konkretny i realny ${ }^{18}$. Wydaje się więc, że należy rozważyć trzy punkty czasowe rozdzielające przygotowanie od dokonania: zabranie rzeczy z półki, schowanie jej do torby lub kieszeni, ustawienie się w kolejce do kasy. W mojej opinii zagrożenie przyjmuje realny charakter dopiero $\mathrm{w}$ momencie ukrycia rzeczy w torbie lub kieszeni ${ }^{19}$. Moim zdaniem należy odrzucić kwalifikowanie jako usiłowania kradzieży wcześniejszego przebywania sprawcy w sklepie, gdyż przedmiot wykonawczy nie jest jeszcze skonkretyzowany i zagrożenie dobra ma charakter abstrakcyjny (przygotowanie). Podobnie, choć mniej kategorycznie, należy ocenić

16 Zob. G. Rejman, op. cit., s. 51-52.

17 Ibidem, s. 52. Autorka analizuje teorię planu w rozdziale Teorie obiektywne w nauce prawa karnego, co może wskazywać na prymat czynników obiektywnych. $\mathrm{W}$ jej książce nie ma jednak oddzielnego rozdziału na temat teorii mieszanych. Wydaje się jednak, że teoria planu jest subiektywno-obiektywna. Szerzej na ten temat zob. Z. Jędrzejewski, Bezprawie usiłowania nieudolnego, Warszawa 2000, s. 104-106.

18 A. Zoll, [w:] A. Zoll, Kodek karny. Komentarz. Część ogólna, t. 1, Warszawa 2007, s. 206. Teoria ta jest szczególnie pomocna do rozdzielenia usiłowania udolnego od nieudolnego. Szerzej na temat teorii dualistycznych zob. Z. Jędrzejewski, op. cit., s. 99-104.

19 Tak też T.L. Krawczyk, Iter delicti kradzieży w supermarkecie (studium przypadku), Pal. 2004, nr 11-12, s. 37. 
zabór towaru z półki. Czynność ta nie różni się przedmiotowo od zachowania legalnego i dlatego moim zdaniem jako usiłowanie kradzieży mogłaby być kwalifikowana wyłącznie na gruncie teorii podmiotowych.

W doktrynie podkreśla się, że

z czysto intuicyjnego (pozaprawnego) punktu widzenia, usiłowanie kradzieży w supermarkecie powinno zaczynać się już w chwili ukrycia skradzionej rzeczy w celu jej wyniesienia poza teren sklepu. Ten właśnie moment, nie zaś dopiero moment podejścia do kas, jest w potocznym przekonaniu chwilą, w której sprawca „robi coś złego”, a zatem dopuszcza się bezprawia kryminalnego ${ }^{20}$.

Nie wydaje się jednak trafne stwierdzenie T.L. Krawczyka, że w praktyce jest to ostatni moment, w którym próba zaboru rzeczy może zostać wykryta i przerwana, co jest kryminalno-politycznym argumentem za kryminalizacją tego zachowania ${ }^{21}$. Zdecydowana większość kradzieży wykrywana jest w momencie przekroczenia bramki kasowej. Nawet jeżeli ochrona sklepu wie o tym, że rzecz została przez sprawcę ukryta, to zatrzymanie następuje dopiero w momencie przekroczenia tej bramki.

Powstaje jednak pytanie, jak kwalifikować (przygotowanie czy usiłowanie) usuwanie zabezpieczenia z rzeczy (kodu) w celu jej kradzieży, jeżeli czyn sprawcy zostanie zatrzymany na tym etapie, na przykład $\mathrm{w}$ wyniku interwencji ochrony ${ }^{22}$. Moim zdaniem zachowanie to stanowi przygotowanie. Sprawca, usuwając zabezpieczenia rzeczy przed kradzieżą, tworzy warunki do przedsięwzięcia czynu zmierzającego bezpośrednio do dokonania, czyli ukrycia rzeczy w kieszeni lub torbie, co stanowi już usiłowanie kradzieży według teorii materialnoobiektywnych. Wydaje się, że nie spełnia przesłanki „dobrowolności” czynnego żalu (art. 15 k.k.) osoba, która widząc zbliżającego się ochroniarza, ukrytą w torbie rzecz odkłada na półkę.

Zgodnie z przyjętą w polskiej nauce teorią zawładnięcia kradzież jest dokonana w momencie zawładnięcia rzeczą przez sprawcę. L. Peiper pisał, że zabór (apprehensio) stanowi bezprawne pozytywne działanie zmieniające dotychczasowy stan władztwa nad rzeczą (status quo). Pole-

20 Ibidem, s. 38.

21 Ibidem.

22 Natomiast przeklejenie kodu kreskowego z innej tańszej rzeczy w celu zapłaty mniejszej ceny należy, według mnie, kwalifikować jako przestępstwo oszustwa, a nie kradzieży.

Nowa Kodyfikacja Prawa Karnego 51, 2019

(C) for this edition by CNS 
ga on na przeniesieniu władztwa i rozszerzeniu swojego stanu posiadania z uszczerbkiem dla dotychczasowego posiadacza.

Akt zaboru składa się z aktu sięgnięcia po rzecz (dotknięcia jej), które stanowi jedynie akt usiłowania i z właściwego zaboru rzeczy czyli zagarnięcia jej w swoje władztwo (apprehensio); to zagarnięcie zmienia przestępstwo usiłowane w przestępstwo dokonane. Okoliczność, czy sprawca zdołał rzecz unieść i zapewnić sobie władztwo nad nią na zawsze, czy na czas dłuższy lub krótszy, pozbawiona jest prawnego znaczenia ${ }^{23}$.

Wskazywano, że istotne jest objęcie rzeczy we własne posiadanie, a następcze rozporządzenie nią jak swoją własnością jest irrelewantne i nie należy do cech obiektywnych przestępstwa, lecz tylko

jako subiektywne zamierzenie sprawcy towarzyszy przedsiębranemu przezeń działaniu. Objęcie rzeczy w posiadanie rozumieć należy jako równoczesne faktyczne jej wyjęcie z posiadania innej osoby, jeżeli zatem ktokolwiek ujął cudzą rzecz w rękę nawet w zamiarze kradzieży, nie zdołał jej jednak usunąc z posiadania właściciela, to nie dokończył jeszcze działania przestępnego kradzieży. Tak złodziej, który, włożywszy rękę do cudzej kieszeni, ujął portmonetkę, ale jej jeszcze z kieszeni nie wyciągnął, albo odwiązał konia od żłobu, ale nie zdążył go jeszcze wyprowadzić ze stajni, jeżeli będzie w tej chwili ujęty, winien będzie usiłowania kradzieży, ponieważ stan posiadania właściciela (kieszeni, stajni) nie został przerwany całkowicie; z chwilą jednak, gdy złodziej wyjął rękę z łupem z cudzej kieszeni albo wyszedł z łupem ze stajni (mieszkania, domu, zagrody — zależnie od przedmiotu i okoliczności kradzieży), to chociażby niezwłocznie wobec pościgu lub innego powodu skradzione rzeczy porzucił, stan faktyczny kradzieży będzie wypełniony i przestępstwo dokonane ${ }^{24}$.

O ile oddzielenie przygotowania od usiłowania kradzieży zwykłej (nie w supermarkecie) jest sporne i zależy od przyjętej koncepcji usiłowania, o tyle ustalenie czasu dokonania kradzieży z reguły nie rodzi wątpliwości. Trudności natomiast pojawiają się w przypadku omawianej kradzieży w sklepie samoobsługowym. Wynikają one, na co zwraca się uwagę w literaturze, z tego, że w tym przypadku rzecz nie zostaje objęta władztwem sprawcy w chwili wyjęcia jej spod władztwa właściciela. Istnieje pewien odcinek czasowy, w którym władztwo sprawuje właściciel,

23 L. Peiper, Komentarz do Kodeksu karnego i Prawa o wykroczeniach, Kraków 1936, s. 541.

24 W. Makowski, op. cit., s. 410-411.

Nowa Kodyfikacja Prawa Karnego 51, 2019

(C) for this edition by CNS 
jak i w pewnym sensie złodziej. Trwa wtedy stan sui generis dwuwładztwa nad rzeczą ${ }^{25}$.

Sprawca od chwili podjęcia rzeczy z półki sklepowej, czego dokonuje z zamiarem przywłaszczenia, jest posiadaczem samoistnym. Jednocześnie jednak, do pewnego momentu właściciel supermarketu sprawuje jeszcze nad rzeczą swego rodzaju kontrolę, bowiem znajduje się ona wciąż w pomieszczeniu, którym ma wyłączne prawo dysponować ${ }^{26}$.

Kradzież jest więc dokonana, jeżeli sprawca jednoznacznie usunie rzecz spod władztwa właściciela sklepu. Powstaje jednak pytanie, czy dokonanie następuje w momencie przejścia przez bramkę kasową, przejścia przez nią bez zatrzymania (na przykład na skutek usunięcia z rzeczy zabezpieczenia) czy też opuszczenia terenu całego obiektu.

Zdaniem T.L. Krawczyka dokonanie ma miejsce w chwili przekroczenia linii kas, ponieważ obszar rozciągający się poza nimi, choć zazwyczaj należy (obligacyjnie lub prawnorzeczowo) do właściciela supermarketu, to na mocy przyjętej konwencji lub regulaminu zrzeka się on wykonywania na nim swoich uprawnień, dopuszczając do przebywania na nim nieograniczonej liczby osób z różnymi przedmiotami ${ }^{27}$.

$\mathrm{O}$ ile bowiem przed linią kas obowiązują pewne reguły mające na celu chronienie władztwa właściciela nad zgromadzonymi w sklepie towarami przed ich zaborem, np. zakaz wchodzenia do sklepu z torbami czy plecakami. [...] Poza linią kas żadne tego rodzaju obostrzenia już nie obowiązują. Właściciel sklepu nie sprawuje zatem nad rzeczami znajdującymi się w tej strefie efektywnej kontroli. Przyjąć więc trzeba, że sprawca, który znalazł się poza linią kas, realnie pozbawia właściciela rzeczy władztwa nad nią, a więc już wtedy dopuszcza się przestępstwa (wykroczenia) kradzieży w formie dokonania ${ }^{28}$.

Przeciwne stanowisko w tej kwestii zdaje się zajmować J. Wojciechowski, który moim zdaniem „przecenia” wagę okoliczności podmioto-

25 T.L. Krawczyk, op. cit., s. 32. Trafnie wskazuje J. Wojciechowski (Analiza pojęcia ,zaboru” jako elementu kradzieży, „Annales UMCS, sectio G” 16, 1969, s. 292), odnosząc się do przypadku uczciwego klienta, który wkłada rzecz do koszyka i zmierza do kasy, że nie uzyskuje on w ten sposób władztwa nad tą rzeczą, mimo że dzierży ten przedmiot fizycznie i obejmuje go w ,ścisły przestrzenny stosunek względem swojej osoby”. U nabywcy brakuje jednak woli władztwa, które "stosownie do poglądów socjalnych, uzyskuje dopiero wtedy, gdy zapłaci cenę towaru lub, jeżeli zwleka z zapłatą długu".

26 Ibidem, s. 32.

27 Ibidem.

28 Ibidem, s. 33.

Nowa Kodyfikacja Prawa Karnego 51, 2019

(C) for this edition by CNS 
wych (woli władania rzeczą przez złodzieja) względem przedmiotowych (faktycznego władztwa), które według mnie jeszcze nie istnieją (kradzież nie jest dokonana). Jego zdaniem

zewnętrzne okoliczności wskazują wówczas wyraźnie, że sprawca od razu „włącza” rzeczy przy pomocy własnej woli do swojego władztwa i dlatego objawia się jako dysponent tych rzeczy, wypierając szersze władztwo przestrzenne, przysługujące dzierżycielowi władztwa nad towarami w sklepie ${ }^{29}$.

$\mathrm{Na}$ takim stawisku stoi także H. Welzel, co według mnie nie może dziwić, gdyż twórca finalnej teorii czynu musi uznawać przewagę okoliczności podmiotowych (woli władania) nad przedmiotowymi. Jego zdaniem w przypadku kradzieży w cudzym obrębie władztwa poprzez objęcie rzeczy we własne fizyczne władania (Körperbereich) kradzież zostaje dokonana, ponieważ następuje ustanowienie władztwa złodzieja (Gewahrsamsexklave) ${ }^{30}$. Przeciwne stanowisko w tej kwestii zajmuje H. Mayer ${ }^{31}$. W polskiej literaturze dominuje stanowisko, wedle którego kradzież jest dokonana w momencie objęcia rzeczy we władanie, nawet przed podejściem do kasy ${ }^{32}$. Wydaje się, że należy jednak przyjąć pogląd mniejszościowy, który reprezentuje T.L. Krawczyk ${ }^{33}$. Kradzież jest dokonana, jeżeli sprawca przejdzie przez bramkę kasową.

Niektórzy autorzy wyróżniają jeszcze szczególny przypadek kradzieży w supermarkecie, w którym sprawca (na przykład pracownik) ukrywa rzecz w sklepie w celu jej późniejszego wyniesienia, wskazując,

29 J. Wojciechowski, op. cit., s. 292-293.

${ }^{30}$ H. Welzel, Der Gewahrsamsbegriff und die Diebstähle in Selbstbedienungsläden, Goltdammer's Archiv für Strafrecht 1960, s. 259.

31 H. Mayer, Zum Begriff der Wegnahme, ,Juristenzeitung” 1962, nr 20, s. 618-619 n.

${ }^{32}$ L. Wilk, [w:] Kodeks karny. Cześć szczególna, red. M. Królikowski, R. Zawłocki, t. 2, Warszawa 2013, s. 527; T. Oczkowski, A. Marek, op. cit., s. 72-75; W. Gutekunst, op. cit., s. 53; T. Bojarski, [w:] T. Bojarski et al., Kodeks wykroczeń. Komentarz, Warszawa 2013, s. 440.

33 Tak też SN w wyroku z dnia 18 maja 1987 r., V KRN 124/87, OSNPG 1988, nr 3 , poz. 28; oraz T. Oczkowski, A. Marek, op. cit., s. 72. Wydaje się, że na takim stanowisku stał także W. Makowski, (Prawo karne. O przestępstwach w szczególności. Wykład porównawczy prawa karnego austryackiego, niemieckiego i rosyjskiego obowiazującego w Polsce, Warszawa 1924, s. 410-411), który kradzież uważał za dokonaną, dopiero gdy złodziej konia opuścił stajnię ze zwierzęciem. 
że w momencie ukrycia kradzież jest już dokonana ${ }^{34}$. Stanowisko to nie wydaje się trafne. Choć właściciel sklepu jest wtedy pozbawiony realnej możliwości wykonywania władztwa nad rzeczą ( na przykład nie może jej sprzedać), czyli spełniony jest aspekt negatywny zaboru (pozbawienie faktycznego władztwa), to nie jest zrealizowany aspekt pozytywny. Sprawca także nie może wykonywać wobec niej czynności odpowiadających uprawnieniom właściciela (nie może jej użyć, sprzedać itp.). Dlatego też ukrycie rzeczy przez pracownika w celu kradzieży należy kwalifikować jako usiłowanie.

Sąd Najwyższy w jednym z wyroków podkreślił, że kradzież jest dokonana z chwilą zawładnięcia rzeczą (objęcia jej w faktyczne władanie), jeżeli temu działaniu towarzyszy cel jej przywłaszczenia. Do przyjęcia dokonania nie jest konieczne wyniesienie rzeczy przez sprawcę poza obręb zakładu pracy, na którego szkodę dokonano zaboru ${ }^{35}$. Zdaniem SN przyjmowanie, że kradzież jest dokonana, kiedy sprawca wyniesie rzecz poza ten obręb, oznacza przyjęcie teorii wyniesienia, która nie zyskała poparcia w doktrynie i orzecznictwie. Już od czasów przedwojen-

34 T. Oczkowski, A. Marek, op. cit., s. 72-73.

35 Wyrok SN z dnia 10 czerwca 1969 r., V KRN 164/69, OSNKW 1969, nr 12, poz. 150. Tak też L. Peiper, op. cit., s. 451. Za kradzież dokonaną uważa on także sytuację, w której sprawcy nie udało się jeszcze opuścić miejsca czynu (na przykład mieszkania lub sklepu) i jeżeli zostanie on zatrzymany, to jest to ujęcie na gorącym uczynku (in flagranti). Analogicznie należy oceniać sytuację, w której sprawca zostaje ujęty w czasie bezpośredniego pościgu (quasi in flagranti). S. Budziński podkreśla (O przestępstwach w szczególności. Wykład porównawczy z uwzględnieniem prawo obowiązujących na Królestwie Polskiem i Galicyi Austryackiej, Warszawa 1883, s. 159), że „,nieprzeszkodzenie sprawcy dla tego, że posiadacz chce go następnie ująć, albo pochwycenie rzeczy szybko nastąpiło, nie odejmuje czynowi cechy zaboru". Moim zdaniem kradzieżą dokonaną, względnie oszustwem, jest także czyn polegający na wydaleniu się z miejsca sprzedaży rzeczy z nią bez zapłacenia ceny. Za usiłowaną natomiast należy uznać kradzież, jeżeli sprawca schowa rzecz do kieszeni lub torby i zostaje zatrzymany w sklepie samoobsługowym, zanim przejdzie przez bramkę i kasę. L. Peiper (op. cit., s. 541) stwierdza wprost, że kradzież jest dokonana przed wydaleniem się z mieszkania lub sklepu. Na takim stanowisku stoi także J. Bafia. Zob. J. Bafia, K. Mioduski, M. Siewierski, Kodeks karny. Komentarz, Warszawa 1987, s. 551. Stanowisko to dominuje w doktrynie. Natomiast zdaniem O. Górniok (op. cit., s. 19) dokonanie kradzieży następuje w chwili wyniesienia mienia poza teren zakładu pracy. Tak też o czasie dokonania kradzieży z włamaniem zob. B. Świątkiewicz, Glosa do wyroku SN z dnia 11 stycznia 1988 r., II KR 343/87, OSP 1990, nr 7-8, s. 653-654.

Nowa Kodyfikacja Prawa Karnego 51, 2019

(C) for this edition by CNS 
nych powszechnie przyjmowano teorię zawładnięcia ${ }^{36}$. W mojej opinii nie należy zaprezentowanego przypadku (kradzież przez pracownika w zakładzie pracy) oceniać identycznie jak kradzież w sklepie samoobsługowym. Obie sytuacje istotnie się różnią, gdyż w ostatnim przypadku sprawca również ma do „pokonania” bramki kasowe i dlatego nie należy przyjmować dokonania, dopóki nie przekroczy on ich linii. Dlatego też kradzież jest dokonana, jeżeli sprawca został zatrzymany na przykład w mieszkaniu pokrzywdzonego i rzecz przygotował już do wyniesienia. Sprawa komplikuje się jednak, jeżeli część rzeczy będzie już przygotowana do wyniesienia, ale sprawca nadal poszukuje innych rzeczy (zabiera je). Wydaje się, że należy zwrócić uwagę na ciągłość i jedność czynu oraz wykluczyć możliwość rozbicia go na części (kradzieże usiłowane i dokonane). W opisie czynu należy jednak wskazać, które rzeczy były już przygotowane do wyniesienia, gdyż zwiększa to stopień społecznej szkodliwości. Wtedy przestępstwo to należy kwalifikować jako usiłowane.

\section{Bibliografia}

Bafia J., Mioduski K., Siewierski M., Kodeks karny. Komentarz, Warszawa 1987.

Blackstone W., Prawo Kryminalne Angielskie, Warszawa 1786.

Bojarski T., [w:] T. Bojarski et al., Kodeks wykroczeń. Komentarz, Warszawa 2013.

Budziński S., O przestępstwach w szczególności. Wykład porównawczy z uwzględnieniem prawo obowiązujacych na Królestwie Polskiem i Galicyi Austryackiej, Warszawa 1883.

Frankowski S., Przestępstwa kierunkowe w teorii i praktyce, Warszawa 1970.

Górniok O., Zagarnięcie mienia społecznego, Warszawa 1976, s. 166-167.

Gutekunst W., Zabór jako sposób zagarnięcia mienia społecznego, NP 1955.

Honig R., Straflose Vor-und Nachtat, Leipzig 1927, s. 96.

Jędrzejewski Z., Bezprawie usiłowania nieudolnego, Warszawa 2000.

Krawczyk L., Iter delicti kradzieży w supermarkecie (studium przypadku), Pal. 2004, nr 11-12.

Krzymuski E., System prawa karnego ze stanowiska nauki i trzech kodeksów obowiąujących w Polsce, Kraków 1921.

Krzymuski E., Wykład prawa karnego ze stanowiska nauki i prawa austryackiego, t. 2, Kraków 1902, s. 236.

Kunze E., Przygotowanie przestępstwa w ujęciu polskiego prawa karnego, Poznań 1991.

36 J. Makarewicz, op. cit., s. 446; L. Peiper, op. cit., s. 541.

Nowa Kodyfikacja Prawa Karnego 51, 2019

(C) for this edition by CNS 
Makowski W., Kodeks karny. Komentarz, Warszawa 1932.

Makowski W., Prawo karne. O przestępstwach w szczególności. Wykład porównawczy prawa karnego austryackiego, niemieckiego i rosyjskiego obowiqzującego w Polsce, Warszawa 1924.

Marek A., [w:] A. Marek, E. Pływaczewski, A. Peczeniuk, Kradzież i paserstwo mienia prywatnego, Warszawa 1985.

Mayer H., Zum Begriff der Wegnahme, Juristenzeitung 1962, nr 20.

Oczkowski T., Marek A., [w:] System prawa karnego, Przestępstwa przeciwko mieniu i gospodarcze, red. R. Zawłocki, t. 9, Warszawa 2011.

Peiper L., Komentarz do Kodeksu karnego i Prawa o wykroczeniach, Kraków 1936, s. 541.

Rejman G., Usiłowanie przestępstwa w prawie polskim, Warszawa 1965.

Śliwiński S., Prawo karne, Warszawa 1946.

Śliwowski J., Glosa do postanowienia SN z dnia 16 grudnia 1957 r., KO 139/51, OSP, poz. 79.

Świątkiewicz B., Glosa do wyroku SN z dnia 11 stycznia 1988 r., II KR 343/87, OSP 1990, $\mathrm{nr} 7-8$.

Welzel H., Der Gewahrsamsbegriff und die Diebstähle in Selbstbedienungsläden, Goltdammer's Archiv für Strafrecht 1960.

Wilk L., [w:] Kodeks karny. Częśś szczególna, red. M. Królikowski, R. Zawłocki, t. 2, Warszawa 2013.

Wojciechowski J., Analiza pojęcia ,zaboru” jako elementu kradzieży, „Annales UMCS, sectio G” 16, 1969.

Wolter W., Reguly wyłaczania wielości ocen w prawie karym, Warszawa 1961.

Zoll A., [w:] A. Zoll, Kodek karny. Komentarz. Część ogólna, t. 1, Warszawa 2007.

\section{The time of attempting and committing theft in a self-service shop}

\section{Summary}

If the place where the theft was committed is a supermarket, establishing the precise time of that attempt is often disputed. It depends on the acceptance of a certain theoretical view about the notion of "an attempt." According to the dominant position adopted in the Polish legal literature, theft is committed at the time of seizing the property, even before approaching the cash register.

Keywords: theft, misappropriation, attempt, commission. 